\title{
Pregnancy-induced hypertension and the neonatal outcome*
}

\author{
Hipertensão arterial na gestação e condições neonatais ao nascimento
}

Hipertensión arterial en la gestación y condiciones neonatales del recién nacido

\author{
Solange Regina Perfetto Chaim ${ }^{1}$, Sonia Maria Junqueira Vasconcellos de \\ Oliveira $^{2}$, Amélia Fumiko Kimura ${ }^{2}$
}

\begin{abstract}
Objectives:This cross-sectional study were to identify the prevalence of pregnancy-induced hypertension and to verify diastolic blood pressure (DBP) association with type of birth and perinatal outcome. Methods: The data were collected from the mothers' records, in the governmental maternity hospital indicated for high-risk pregnancies, in São Paulo city. Results: During hospitalization, 62.1\% had systolic blood pressure $\geq 160 \mathrm{mmHg}$ and $49.6 \%$ had a DBP $\leq 110 \mathrm{mmHg}$. There was no significant association of DBP ( $\mathrm{p}=0.799)$. The frequency of caesarean section was $64.5 \%, 28.9 \%$ for normal birth, and $6.6 \%$ for forceps; $93.4 \%$ were live born, $81.0 \%$ weighed $\geq 2,500 \mathrm{~g}, 10.6 \%$ were premature, $68.1 \%$ were born with adequate gestational age, $84.0 \%$ and $99.2 \%$ had APGAR score $\geq 7$ at 1 st and 5 th minutes, respectively. Conclusion: The DBP e" $110 \mathrm{mmHg}$ was associated with low birth weight $(\mathrm{p}=0.002)$ and prematurity $(\mathrm{p}=0.013)$.
\end{abstract}

Keywords: Hypertension; Pregnancy complications; Pregnancy outcome; Pre-eclampsia; Infant, newborn

\section{RESUMO}

Objetivos: Identificar a prevalência da hipertensão arterial na gravidez e associar a pressão arterial diastólica (PAD) materna com tipo de parto e condições do neonato ao nascimento. Métodos: Estudo transversal, retrospectivo realizado por meio de análise de dados de prontuários de parturientes internadas em uma maternidade pública, da cidade de São Paulo, referência para gestação de alto risco. Resultados: A prevalência de hipertensão foi de 13,9\%. Verificou-se que $62,1 \%$ das parturientes apresentaram pressão arterial sistólica $\geq 160 \mathrm{mmHg}$; $49,6 \%$ PAD $\geq 110 \mathrm{mmHg}$ na internação. A PAD não apresentou associação significativa com o tipo de parto $(p=0,799)$. A freqüência de cesárea foi $64,5 \%$, normal $28,9 \%$ e fórcipe $6,6 \%$. Dos recém-nascidos, $93,4 \%$ foram nativivos, $81 \%$ apresentaram pêso $\geq 2.500 \mathrm{~g}, 10,6 \%$ eram prematuros, 68,1\% adequados para idade gestacional, índice de APGAR $1 . .^{\circ}$ e $5 .{ }^{\circ}$ minutos $\geq 7$ em $84,0 \%$ e $99,2 \%$, respectivamente. Conclusão:A PAD $\geq 110 \mathrm{mmHg}$ apresentou associação significativa com baixo peso $(\mathrm{p}=0,002)$ e prematuridade $(\mathrm{p}=0,013)$.

Descritores: Hipertensão; Complicações na gravidez; Resultado da gravidez; Pré-eclâmpsia; Recém-nascido

\section{RESUMEN}

Objetivos: Identificar la prevalencia de la hipertensión arterial en el embarazo y asociar la presión arterial diastólica (PAD) materna con el tipo de parto y condiciones del neonato al nacer. Métodos: Estudio transversal, retrospectivo realizado por medio del análisis de datos de historias clínicas de parturientas internadas en una maternidad pública, de la ciudad de Sao Paulo, referencia para la gestación de alto riesgo. Resultados: La prevalencia de hipertensión fue de 13,9\%. Se verificó que 62,1\% de las parturientas presentaron presión arterial sistólica $\geq$ $160 \mathrm{mmHg} ; 49,6 \%$ PAD $\geq 110 \mathrm{mmHg}$ en el internamiento. La PAD no presentó asociación significativa con el tipo de parto ( $\mathrm{p}=0,799$ ). La frecuencia de cesárea fue $64,5 \%$, normal $28,9 \%$ y con forcep $6,6 \%$. De los recién nacidos, 93,4\% fueron nativivos, $81 \%$ presentaron peso $\geq 2.500 \mathrm{~g}, 10,6 \%$ eran prematuros, $68,1 \%$ adecuados para la edad gestacional, índice de APGAR $1 .{ }^{0}$ y $5 .{ }^{\circ}$ minutos $\geq 7$ en el $84,0 \%$ y $99,2 \%$, respectivamente. Conclusión: La PAD $\geq 110 \mathrm{mmHg}$ presentó asociación significativa con bajo peso $(\mathrm{p}=0,002)$ y prematuridad $(\mathrm{p}=0,013)$.

Descriptores: Hipertensión; Complicaciones en el embarazo; Resultado de la gravidez; Pre-eclampsia; Recién nacido

* Study caneid out at Hospital e Maternidade Leonor Mendes de Barros - São Paulo (SP), Braz̧il.

${ }^{1}$ Master in Nursing, Obstetric Nurse of the Hospital e Maternidade Leonor Mendes de Barros. São Paulo (SP), Brazil.

${ }^{2}$ PhD, Professor of the Maternal-Infant and Psychiatric Health of the Universidade de São Paulo College of Nursing- São Paulo (SP), Brazil. 


\section{INTRODUCTION}

Pregnancy is a physiological phenomenon for most women. However, some develop problems during its evolution, putting both the mother's and the conceptus' health at sake. Pregnancy-induced hypertension is one of the maternal diseases that causes the most detrimental effects to the maternal, fetal, and neonatal organisms.

Pregnancy-induced hypertension is the general classification for hypertension diseases during pregnancy, which include pregnancy-induced hypertension (without proteinúria), pre-eclampsia (with proteinúria), and eclampsia (pre-eclampsia with convulsions). This disease is responsible for high maternal and perinatal morbidity and mortality rates, and is one of the main public health problems $^{(1-2)}$.

According to the Health Ministry, hypertension during pregnancy, depending on the severity level, is considered a risk factor, which, associated with individual characteristics, unfavorable socioeconomic conditions, certain obstetric histories and clinical problems could trigger harms to the maternal-fetal binomial ${ }^{(3)}$.

For the conceptus, the most common consequences associated with hypertension diseases are the restriction of intra-uterine growth, low birth weight, and prematurity ${ }^{(2,4)}$.

The changes in fetal growth are assessed by means of anthropometric measurements, such as, birth weight and gestational age. These variables help to determine the intra-uterine growth curves, thus characterizing the newborn (NB). The NB should be compared to a similar population based on the racial, ethnical, and population factors ${ }^{(5)}$.

NBs can be classified by comparing their weights against the gestational age, employing the intra-uterine growth curves by means of standard deviations or percentiles. This allows for classifying them as adequate to their gestational age (AGA), if ranked between the $10^{\text {th }}$ and $90^{\text {th }}$ percentile in a certain gestational period; small for the gestational age (SGA) if below the 1oth percentile, and big for the gestational age (BGA) if above the $90^{\text {th }}$ percentile ${ }^{(5-6)}$.

The postnatal gestational age can be determined by the method proposed by Capurro et al. in $1977^{(7)}$. This method, which evaluates the physical and neurological characteristics, or their combination, remains common in many maternities.

The most common method used today to evaluate fetal maturity in the delivery room is the New Ballard Method. The scores in this method range between 10 (corresponding to a gestational age of 20 weeks) and 50 (corresponding to a gestational age of 44 weeks), and it is more accurate if performed in the 12 first hours of life. Moreover, it allows for the evaluation of extremely premature $\mathrm{NBs}^{(8)}$.

The World Health Organization, in 1993, refers that NB with low birth weight are those born with less than 2500g, regardless of the gestational age. Pre-term NBs are those whose birth occurs before completing 37 gestational weeks ${ }^{(9)}$.

Therefore, it was considered suitable to perform this study at the Leonor Mendes de Barros Hospital and Maternity, which delivers care to women with high-risk pregnancies and offers specialized care in obstetrics and neonatology. Furthermore, it is one of the reference health institutions in the great São Paulo region.

\section{OBJECTIVES}

The purpose of this study was to identify the prevalence of hypertension during pregnancy, and associate maternal diastolic blood pressure with the type of delivery and the neonate's condition at birth.

\section{METHODS}

This is a cross-sectional study using retrospective data collection from the patient record of pregnant women with hypertension and their association with the type of delivery and the NB's vitality conditions.

The study was performed at the Leonor Mendes de Barros Hospital and Maternity, a public institution, part of the Single Health System. The hospital is located in the East of São Paulo city. An analysis was performed on 5602 birth records from January $1^{\text {st }}$ to December $31^{\text {st }} 1999$. Of the women, 778 were diagnosed with hypertension in their pregnancies. The study sample consisted of $126(16.2 \%)$ records, randomly selected. Five of these referred to multiple pregnancies, and were, therefore, excluded.

Hypertension was identified based on the definition by the Australian Society of the Study of Hypertension in Pregnancy ${ }^{(2)}$ and that of the Working Group Report on High Blood Pressure in Pregnancy ${ }^{(10)}$, which establish blood pressure levels $\geq 140 / 90 \mathrm{mmHg}$ or hypertension diagnosis marked on the record.

The Maternity's Ethics Committee approved the study project. Since this study used patient records as the source for the data, the main researcher signed a Responsibility Term to ensure the patients' anonymity would be preserved.

The records were initially identified by referring to the birth book of the obstetric unit, which holds information about the hospital record, the notes on the pregnant women's blood pressure and the type of delivery. This information allowed for identifying the medical record at the Medical File Service, to then carry out the data collection. 
The data were stored in an Excel databank. Descriptive analysis was performed, of which data are presented in the tables. The comparative analysis was performed using Chi-square test or Exact Fisher test to test the homogeneity of the groups regarding the quantitative variables. The Student's t test was used to compare the quantitative variable means. The adopted level of significance was $5 \%$ alpha error.

\section{RESULTS}

The prevalence of hypertension among the pregnant women hospitalized in the Leonor Mendes de Barros Maternity Hospital was 13.9\% (778/5602). The data show that $95.8 \%$ of the women received prenatal care;
64.5\% were between 20 and 34 years old (average 29.4 years), $72.2 \%$ were white, $78.5 \%$ had two or more pregnancies, and $52.9 \%$ were multiparous. The findings revealed that $92.6 \%$ and $94.6 \%$ of the women did not have a history of prematurity and stillbirth, respectively.

During their hospitalization, it was verified that $49.6 \%$ of the pregnant women presented a diastolic blood pressure (DBP) $110 \mathrm{mmHg}$ and 46.3\% had edema, of which $54.5 \%$ were classified as degree 1 . The systolic blood pressure ranged between 140 and $230 \mathrm{mmHg}$ and diastolic ranged between 90 and $160 \mathrm{mmHg}$. The values of $160 \mathrm{mmHg}$ for systolic blood pressure and $100 \mathrm{mmHg}$ for diastolic were the most frequent, with $23.1 \%$ and $35.5 \%$ respectively.

There was no significant association between DBP

Table 1 - Mothers' age, type of delivery, and gestational age according to the levels of diastolic blood pressure

\begin{tabular}{|c|c|c|c|c|c|c|c|}
\hline \multirow{3}{*}{ Variables } & \multicolumn{6}{|c|}{ Diastolic blood pressure (mmHg) } & \multirow{3}{*}{$p$} \\
\hline & \multicolumn{2}{|c|}{$\geq 110$} & \multicolumn{2}{|c|}{$<110$} & \multicolumn{2}{|c|}{ Total } & \\
\hline & $\mathrm{n}$ & $\%$ & $n$ & $\%$ & $n$ & $\%$ & \\
\hline \multicolumn{8}{|c|}{ Mothers' age (years) } \\
\hline$\leq 19$ & 6 & 10,0 & 7 & 11,5 & 13 & 10,7 & \multirow{3}{*}{0,668} \\
\hline $20 \vdash 36$ & 42 & 70,0 & 41 & 67,2 & 83 & 68,6 & \\
\hline$\geq 36$ & 12 & 20,0 & 13 & 21,3 & 25 & 20,7 & \\
\hline \multicolumn{8}{|c|}{ Type of delivery } \\
\hline Cesarean & 40 & 66,7 & 38 & 62,3 & 78 & 64,5 & \multirow{3}{*}{0,799} \\
\hline Natural & 17 & 28,3 & 18 & 29,5 & 35 & 28,9 & \\
\hline Forceps & 3 & 5,0 & 5 & 8,2 & 8 & 6,6 & \\
\hline \multicolumn{8}{|c|}{ Gestational age* } \\
\hline Pre-Term & 10 & 17,9 & 2 & 3,5 & 12 & 10,6 & \multirow[t]{2}{*}{0,013} \\
\hline Term & 46 & 82,1 & 55 & 96,5 & 101 & 89,4 & \\
\hline
\end{tabular}

* Eight NB were excluded (seven stillbirths and one neomorto)

Table 2. Infants' conditions at birth

\begin{tabular}{|c|c|c|}
\hline NB's conditions & $\mathbf{n}$ & $\%$ \\
\hline \multicolumn{3}{|l|}{ Vitality $(n=121)$} \\
\hline Live born & 113 & 93,4 \\
\hline Stillborn & 7 & 5,8 \\
\hline Neomorto & 1 & 0,8 \\
\hline \multicolumn{3}{|l|}{ Weight (grams) $(\mathrm{n}=121)$} \\
\hline$\geq 2500$ & 98 & 81,0 \\
\hline $2500 \dashv 1500$ & 15 & 12,4 \\
\hline $1500+1000$ & 5 & 4,1 \\
\hline$<1000$ & 3 & 2,5 \\
\hline \multicolumn{3}{|c|}{ Classification of weight according to gestational age $\left(n=113^{*}\right)$} \\
\hline Adequate for gestational age & 77 & 68,1 \\
\hline High for gestational age & 24 & 21,2 \\
\hline Low for gestational age & 12 & 10,6 \\
\hline \multicolumn{3}{|c|}{ APGAR at the 1 st minute $\left(n=113^{*}\right)$} \\
\hline$\geq 7$ & 95 & 84,1 \\
\hline$<7$ & 18 & 15,9 \\
\hline \multicolumn{3}{|c|}{ APGAR at the 5 th minute $\left(n=113^{*}\right)$} \\
\hline$\geq 7$ & 112 & 99,2 \\
\hline$<7$ & 1 & 0,8 \\
\hline
\end{tabular}

* Eight NB were excluded (seven stillbirths and one neomorto) 
and age group $(p=0.668)$ and the type of delivery $(p=0.799)$. The highest percentage $(17.9 \%)$ of preterm NBs occurred among pregnant women with DPB e" $110 \mathrm{mmHg}$. This shows a significant association between prematurity and pressure levels $(\mathrm{p}=0.013)$ (Table 1).

The results regarding the perinatal conditions showed a prevalence $(93.4 \%)$ of live births. Regarding the gestational age, the findings show that $12(10.6 \%) \mathrm{NBs}$ were preterm. According to the adequacy of birth weight to gestational age, it was observed that most $(68.1 \%) \mathrm{NBs}$ were AGA. As to the APGAR, most presented a value e $\geq 7$ in the first and fifth minute of life. Only one NB had a APGAR $<7$ in the fifth minute of life (Table 2).

There was a statistical association between DBP and NB weight. The group of women with DBP e $\geq 110$ $\mathrm{mmHg}$ presented a smaller mean, median, and maximum NB weight compared to the groups with $\mathrm{BBP}<110 \mathrm{mmHg}$ (Table 3).

\section{DISCUSSION}

The prevalence of hypertension observed in this study is in agreement with the data found in the United States, where approximately $10 \%$ of the 75,000 deliveries occurred in Parkland Hospital were diagnosed with pregnancy-induced or -aggravated hypertension ${ }^{(4)}$. In Brazil, it was also found a $10.3 \%$ frequency in the Teaching Maternity of the Rio de Janeiro Federal University ${ }^{(11)}$.

Most women in this study received prenatal care $(95.8 \%)$. This care has an extremely important role in prevention maternal and perinatal morbidity and mortality, since hypertension in pregnancy cannot be avoided, but maternal death usually can. Eclampsia is now less frequent in the USA because most pregnant women get appropriate prenatal care. The $17^{\text {th }}$ edition of the book Willians Obstetrics states that the incidence of eclampsia in Parkland Hospital has been one in every 700 births, over the past 25 years. In the period from 1983 to 1986, the incidence was one in every 1150 births, and from 1990 to 1994 it was about one in every 2300 births $s^{(4)}$.

Regarding the clinical conditions in hospital admission, it was observed that approximately half the women presented DBP PAD e" $110 \mathrm{mmHg}$ and edema, which indicates that the disease is severe ${ }^{(12)}$. The rise in pressure values is an important marker of the intensity of vasoespasmo in different organs, probably due to the endothelial damage resulting in deficient nutrition and hypoxia $^{(13)}$. In the present study, the mean BP was 163.2/ $107.5 \mathrm{mmHg}$ and the minimum and maximum values for systolic and diastolic pressures were 140 to 230 $\mathrm{mmHg}$ and 90 to $160 \mathrm{mmHg}$, respectively. Similar values were found among 760 hypertensive pregnant women admitted to a hospital in South Africa, with an average blood pressure of 163.0/108.8 $\mathrm{mmHg}$, systolic pressure ranged from 140 to $270 \mathrm{mmHg}$, and diastolic from 90 to $190 \mathrm{mmHg}^{(14)}$. In Brazil, a more recent study found that the diastolic blood pressure levels increased from 99 to $111 \mathrm{mmHg}$ as the proteinuria levels moved from absent to $\geq 2 \mathrm{~g}$, suggesting an association between high BP levels and harms to the renal function ${ }^{(13)}$.

Regarding the delivery, no statistical association was found $(p=0.799)$ between the type of delivery and diastolic pressure, though cesarean deliveries prevailed with $64.5 \%$. Similar data was found in São Paulo Hospital when the global occurrence of cesarean was $73.3 \%$, reaching $82 \%$ in hypertension women with high proteinuria $^{(13)}$. On the other hand, in Umtata General Hospital, the prevalence of cesareans among hypertensive women was $30.2 \%{ }^{(14)}$.

As to the perinatal data, $93.4 \%$ of women had live births, $0.8 \%$ of early neonatal death, likely due to multiple organ and system failure. The frequency of stillbirths was $5.8 \%$. Higher rates $(11.2 \%)$ were found in the study mentioned previously ${ }^{(14)}$. The NBs weight ranged between $560 \mathrm{~g}$ and $6100 \mathrm{~g}$, with an average weight of 3060g. The average weight was statistically associated $(p=0.002)$ with the DBP levels. This means that women with DBP PAD e $\geq 110 \mathrm{mmHg}$ had NBs with lower weights. Research performed in our environment found that NBs of hypertensive women presented an average weight between $2.963 \mathrm{~g}$ and $1.607 \mathrm{~g}$, according to proteinuria levels from absent to $\geq 2 \mathrm{~g}$, respectively ${ }^{(13)}$.

As to prematurity, it was verified that $12(10.6 \%)$ $\mathrm{NBs}$ were preterm. A higher prevalence $(11.3 \%$ to $78.3 \%$ ) was observed in a previously mentioned study, performed with 334 hypertensive pregnant women ${ }^{(13)}$. NB prematurity is a common complication of hypertensive disease, either due to the spontaneous labor

Table 3 - Mean, standard deviation (sd), median, minimum and maximum birth weight values according to the classification of diastolic blood pressure (DBP)

\begin{tabular}{lcccccc}
\hline DBP & \multicolumn{7}{c}{ Birth weight } \\
\cline { 2 - 7 } & $\mathbf{n}$ & Mean & sd & Median & Minimum & Maximum \\
\hline$\geq 110 \mathrm{mmHg}$ & 60 & 2,816 & 884,9 & 2,960 & 900 & 5,350 \\
$<110 \mathrm{mmHg}$ & 61 & 3,300 & 805,5 & 3,310 & 560 & 6,100 \\
\hline
\end{tabular}

$\mathrm{p}=0.002$ (Stduent $\mathrm{t}$ Test) 
or to the obstetric conduct of interrupting the pregnancy due to the compromised maternal-fetal health. A study performed in our environment found a higher relative risk $(R R=1.36)$ for prematurity in pregnant women with chronic hypertension compared to a group with pregnancy-induced hypertension ${ }^{(11)}$. Prematurity increases perinatal morbidity and mortality rates with possible immediate or late sequels, requiring public policies that offer support to these neonates ${ }^{(13)}$.

In the present study, although about half the women presented severe BP levels, only $10.6 \%$ of the NBs were classified as SGA. A recent study found that both gestational and chronic hypertension increased the relative risk for SAG in 2.10 and 1.87, respectively ${ }^{(11)}$.

Prematurity, restricted intrauterine growth, and low birth weight were the outcomes found in a retrospective cohort study among 1308 hypertensive pregnant women. Premature delivery was more frequent among women with severe pre-eclampsia ${ }^{(15)}$.

There was a significant association $(\mathrm{p}=0.013)$ between DBP levels and gestational age. The group of women with $\mathrm{DBP} \geq 110 \mathrm{mmHg}$ presented a higher percentage of preterm NBs $(17.9 \%)$.

There also was a significant association $(p=0.002)$ between DBP and NB weight. A study performed with 234 hypertensive pregnant women without proteinuria, found a reduction in birth weight of $68,5 \mathrm{~g}$ associated to a $5 \mathrm{mmHg}$ rise in the daily mean $\mathrm{DBP}^{(16)}$. Similarly, a study with $307 \mathrm{NBs}$ of women with pre-eclampsia and severe pre-eclampsia found that birth weight was reduced in about $5 \%$ and $12 \%$, respectively ${ }^{(17)}$.

For the Australian Society of the Study of Hypertension

\section{REFERENCES}

1. Chen XK, Wen SW, Smith G, Yang Q, Walker M. Pregnancy-induced hypertension is associated with lower infant mortality in preterm singletons. BJOG. 2006; 113(5):544-51.

2. Brown MA, Hague WM, Higgins J, Lowe S, McCowan L, Oats J, Peek MJ, Rowan JA, Walters BN; Austalasian Society of the Study of Hypertension in Pregnancy. The detection, investigation and management of hypertension in pregnancy: full consensus statement. Aust N Z J Obstet Gynaecol. 2000; 40(2):139-55.

3. Brasil. Ministério da Saúde. Secretaria de Assistência à Saúde. Gestação de alto risco. $4^{\mathrm{a}}$ ed. Brasília: Divisão Nacional de Saúde Materno-Infantil; 2000.

4. Cunningham FG, MacDonald PC, Gant NF, Leveno KJ, Gilstrap LC, Hankins GDV, Clark SL. Distúrbios hipertensivos na gravidez. In: Cunningham FG, MacDonald PC, Gant NF, Leveno KJ, Gilstrap LC, Hankins GDV, Clark SL. Williams obstetrícia. 20a ed. Rio de Janeiro: Guanabara Koogan; 2000. cap. 10, p. 607-52.

5. Volkmer DFV, Ribeiro MAS, Moll RLF, Varella IRS, Magdaleno SEM. Rotinas do atendimento na sala de parto. in Pregnancy, about $25 \%$ of children of mothers with pre-eclampsia are small for the gestational age ${ }^{(2)}$.

In the evaluation of birth conditions, according to the APGAR Index, it was verified that most NBs $(84.1 \%$ and $99.2 \%$ ) presented a value greater or equal to seven in the first and fifth minutes of life, respectively. The relative risks of obtaining an APGAR value smaller than seven in the first and fifth minutes of life in women with pregnancy-induced hypertension and chronic hypertension were 1.26 and $1.65 ; 1.45$ and 1.49 , respectively ${ }^{(11)}$.

\section{CONCLUSION}

Due to the complex differential diagnosis and the limitations of studies using data from patient records, it was not possible to classify the different types of hypertension disorders. Thus, the data were analyzed considering only the occurrence of pregnancy-induced hypertension, which revealed a prevalence of $13.9 \%$. The present study results showed a low stillbirth rate and highlighted low birth weight and prematurity as the main perinatal consequences. An early diagnosis of the hypertension in addition to a suitable intervention meant higher chances of having a pregnancy without complications to the mother and negative effect's to the fetus' health.

Although the results of the present study date back eight years, current national literature data ${ }^{(18)}$ state that pregnancy-induced hypertension is among the four main causes of maternal death in Brazil. This demonstrates that this disease remains prevalent.

In: Nader SS, Pereira DN. Atenção integral ao recémnascido: guia de supervisão de saúde. Porto Alegre: Artmed; 2004. p.27-44.

6. Ramos JLA, Leone CR, coordenadores. Recém-nascido de baixo peso. São Paulo: Sarvier; 1986.

7. Capurro H, Konichezky S, Fonseca D, Caldeyro-Barcia R. A simplified method for diagnosis of gestational age in the newborn infant. J Pediatr. 1978; 93(1):120-2.

8. Gomella TL, Cunningham MD, Eyal FG, Zenk KE. Neonatologia: manejo, procedimentos, problemas no plantão, doenças e farmacologia neonatal. $5^{\mathrm{a}} \mathrm{ed}$. Porto Alegre: Artmed; 2006. cap. 3, p.47-55.

9. Organização Mundial da Saúde. Classificação Estatística Internacional de Doenças e Problemas Relacionados à Saúde. $10^{a}$ revisão (CID - 10). 8 a ed. Centro Colaborador da OMS para Classificação de Doenças em Português. São Paulo: Editora da Universidade de São Paulo (EDUSP); 2000.

10. Working Group Report on High Blood Pressure in Pregnancy. National High Blood Pressure Education Program. Bethesda (MD): National Institutes of Health; 2000. (NIH Publication No.00-3029). 
11. Oliveira CA, Lins CP, Sá RAM, Netto HC, Bornia RG, Silva NR, Amim Junior J. Síndromes hipertensivas da gestação e repercussões perinatais. Rev Bras Saúde Matern Infant. 2006; 6(1):93-8.

12. Neme B. Doença hipertensiva específica da gestação: préeclampsia, eclampsia. In: Rezende J. Obstetrícia. 10a ed. Rio de Janeiro: Guanabara Koogan; 2005. p.703-48.

13. Coelho TM, Martins MG, Viana E, Mesquita MRS, Camano L, Sass N. Proteinúria nas síndromes hipertensivas da gestação: prognóstico materno e perinatal. Rev Assoc Med Bras (1992). 2004; 50(2):207-13.

14. Buga GA, Lumu SB. Hypertensive disorders of pregnancy at Umtata General Hospital: perinatal and maternal outcomes. East Afr Med J. 1999; 76(4):217-22.

15. Xiong X, Mayes D, Demianczuk N, Olson DM, Davidge
ST, Newburn-Cook C, Saunders LD. Impact of pregnancyinduced hypertension on fetal growth. Am J Obstet Gynecol. 1999; 180(1 Pt 1):207-13. Comment in: Am J Obstet Gynecol. 2002; 186(5):1105; author reply 1106.

16. Waugh J, Perry IJ, Halligan AW, De Swiet M, Lambert PC, Penny JA, et al. Birth weight and 24-hour ambulatory blood pressure in nonproteinuric hypertensive pregnancy. Am J Obstet Gynecol. 2000; 183(3):633-7.

17. Odegard RA, Vatten LJ, Nilsen ST, Salvesen KA, Austgulen R. Preeclampsia and fetal growth. Obstet Gynecol. 2000; 96(6):950-5. Comment in: Obstet Gynecol. 2001; 97(4):640.

18. Tanaka ACD'A. Uma aula e muitas lições sobre a mortalidade materna. J Rede Feminista de Saúde. 2006; 28:7-9. 